\title{
The importance of pre-tensioning cable bolts used to reinforce of arch yielding support
}

\author{
Zbigniew Rak $^{1, *}$, Jerzy Cieślik $^{1}$, Jerzy Stasica $^{1}$, Pavel Dvořák ${ }^{2}$ \\ ${ }^{1}$ AGH University of Science and Technology, Cracow, Poland \\ ${ }^{2}$ Minova Bohemia s.r.o., Ostrava, Czech Republic
}

\begin{abstract}
Widespread in Polish hard coal mining, cable bolts are used to reinforce the arch yielding support of roadways. This article attempts to prove that change in approach to long bolting technology can bring significant benefits in terms of improving the stability of roadways, including limiting the development of the fracturing zone in the roof, and ultimately also increasing the frame spacing of arch yielding support. The article contains the results of numerical calculations using the finite element method showing the effect of pre-tensioning on the work of cable bolts installed in a situation when a zone of a fractured rock mass appeared in a roof excavation. As a result of the calculations, the dependence of the final vertical displacements of the roadways roof on different pre-tensioning variants of the cable bolts was presented. The second part of the article presents the practical aspects of the use of cable bolts with pre-tensioning in reinforcing the rock mass and arch yielding support of roadways. In addition, the article identifies the developments in bolting technology which could lead to an increase in work safety and reduce the costs of arch yielding support.
\end{abstract}

Keywords: reinforcement of support, arch yielding support, cable bolts, pre-tensioning

\section{Reinforcing the arch yielding support with the use of cable bolts in coal mining in Poland and the Czech Republic}

Since the 1990s, roof boltings have been used in Polish and Czech hard coal mining (in Upper Silesian and Lublin Coal Basins) to reinforce the sets of arch yielding supports. Rock bolting the support arches is performed mainly to increase the load capacity of sets, which results in improved stability of supports of excavations. This is proven not only by observations and results of excavation measurements, but also by site surveys performed during extraction, which demonstrated that appropriately used bolts greatly increase the load capacity of arch support [1]. The main objective of using cable bolts in practice is, however, the possibility of remove sidewall arches of roadway arch supports at longwall-gateroad junction. Cable bolts eliminate the necessity of the use of props, which is very labour-consuming and not always practicable due to intersection dimensions.

\footnotetext{
*Corresponding author: zrak@agh.edu.pl
} 
Supports of excavations are mostly reinforced by rock bolting the arches of support to the rock mass using cable bolts. Furthermore, sometimes the rock mass is reinforced in the fields between the arch support using rock bolts. This system is analogous to the one used, for example, in deep ore mines (Fig. 1) [2, 3]. In Poland and the Czech Republic, cable bolts are connected to the arch support using V-stringer, usually made from V29 or V32 steel profiles. The binding joists are usually made from long straight connectors, i.e. 4.5 to $6.0 \mathrm{~m}$ or short sections, i.e. from $0.3 \mathrm{~m}$ to $0.5 \mathrm{~m}$ longer than the span of the arch support (Fig. 2) [4]. The steel stringers are connected to the support using screws, further stabilising the structure of the support. As a rule, cable bolts are installed using two or three resin cartridges (usually Lokset with a length of $0.6 \mathrm{~m}$ each), thus the length of the bonding section is approx. $1.5 \mathrm{~m}$. The Polish and Czech mining normally uses cable bolts with a length of $6.0 \mathrm{~m}$ to $11.0 \mathrm{~m}$. The length of these bolts depends on the range of the anticipated failure zone above the excavation. This is especially important for excavations which outline the longwall. In this case cable bolts are used not only to support set arches, but also facilitate the disconnecting of several (usually 4 to 6) sidewall arches of the arch support at an intersection with the wall.

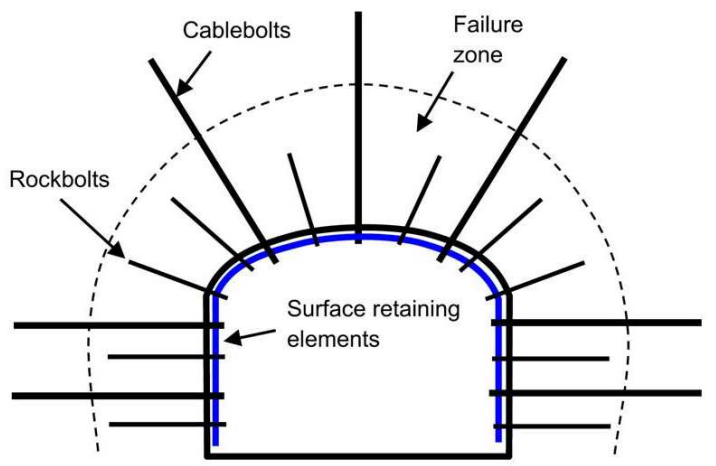

Fig. 1. Methodology of rock bolting in deep metal mines [2].

After disconnecting the sidewall arches at longwall-gateroad junction, cable bolts are the only reinforcement of an incomplete arch support.
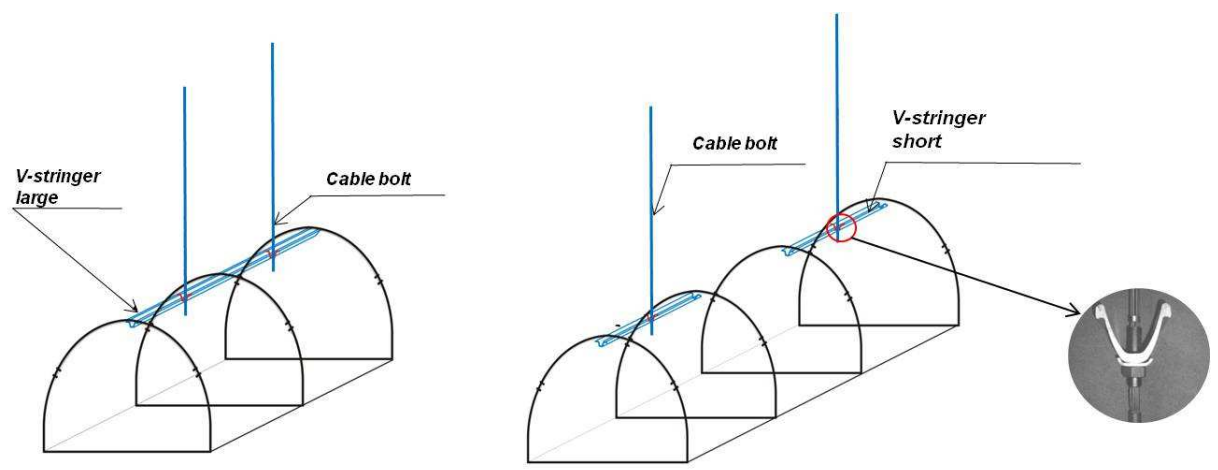

Fig. 2. Exemplary reinforcement schemes of arch support by cable bolts [4].

In the Polish and Czech mining industry, IR cable bolts are used the most. Such bolts are composed of several untwisted spring steel wires clamped with several bands along the length of the strand. The bolt head is a threaded rope socket, whose internal, conically profiled surface is used to fasten the individual wires using a single steel wedge (Fig. 3). 


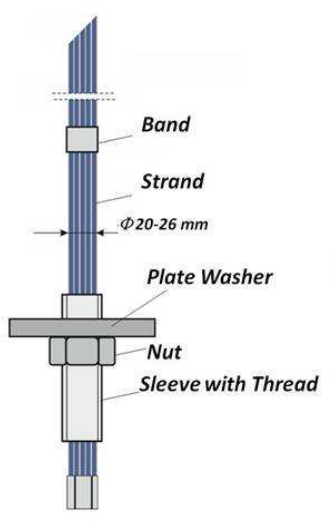

A

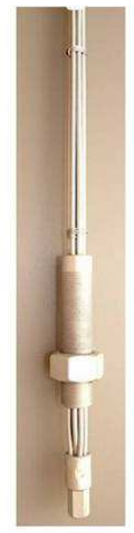

$B$

Fig. 3. IR cable Bolt; A) scheme, B) photo: www. interram.pl.

The load capacity of these bolts depends on the type and ranges between 280 and $470 \mathrm{kN}$. For several years now, there has been a cable bolt solution in place facilitating its installation along the entire length using the injection technique, employing liquid two-component resin or mineral binding agents. These, however, are used relatively infrequently. The typical method of securing roof excavations in the Bogdanka Mine is to reinforce the arch support using IR bolts and reinforce the rock mass with rock bolts, as shown in Fig. 4. Due to the problems with the mechanisation of rebar bolts installation in the foreheads of driven excavations, in mines are used only cable bolts. The installation of bolts takes place several dozen to several hundred metres away from the face of the driven excavation, thus in an already fractured rock mass. Therefore, cable bolts play an incredibly important role in the quality of excavation maintenance.

\section{The conditions of interaction between IR cable bolts, the support and the rock mass}

Filling the void between the arches of the support and the rock mass and pre-tensioning the bolts guarantee the proper interaction between the bolts, support and rock mass.

\subsection{Filling the void between the arches of the support and the rock mass}

One of the proven methods of filling the void between the support and the rock mass is the use of a low compressible lining usually based on the bullflex system [5, 6, 7]. A correctly constructed excavation lining with bolted roof arches is presented in Fig 5. Bags extended along the length of roof arches are filled with mineral and cement binder with a relatively short binding time and uniaxial compressive strength exceeding $20 \mathrm{MPa}$. Pumps for mineral binder grout, located near the face, are used for this purpose. In the case of a driven excavation, the lining, in order for it to serve its purpose, should be constructed on an ongoing basis. Such a solution makes it possible to apply the support and obtain a uniform load on roof arches very quickly. Fig. 5 presents the pattern of interaction between the rock bolt, the rock mass and support in the case of the lining being constructed correctly (item A). 


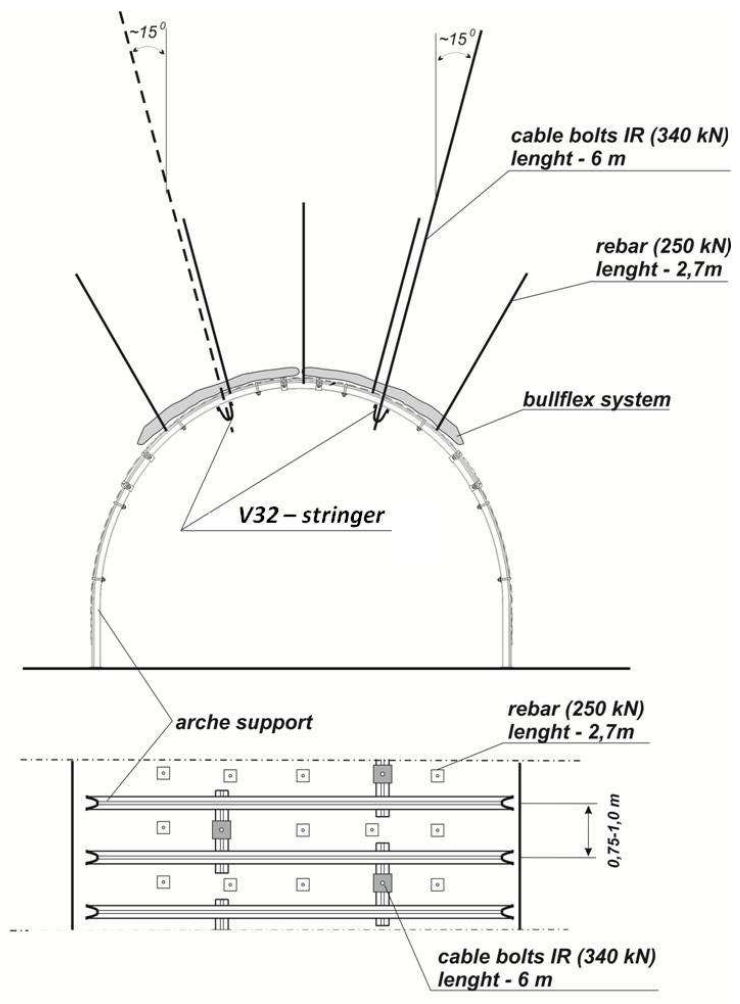

Fig. 4. Exemplary bolting scheme of maingate in LW Bogdanka mine.

Manual lining or lack thereof results in the bolt, directly after installation, not interacting with the rock mass. It is impossible to pretension the bolt, as this could result in raising the support. The interaction between the bolts and the support starts only after rock mass cracks and additional load being placed on the set arches. Therefore, rock mass reinforcement and the reduction of its cracking through bolting is not achieved.

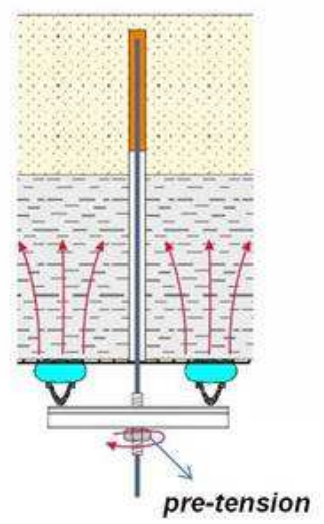

$A$

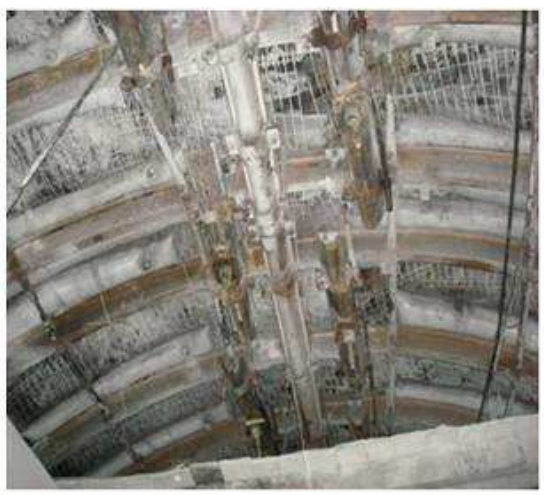

$B$

Fig. 5. Bolted roof yielding arches in the roadway with bullflex system; A) scheme, B) a general view. 


\subsection{Pre-tensioning of cable bolts}

Cable bots reinforcing the support and the rock mass are usually installed several dozen to several hundred metres away from the forehead of the driven excavation. After their installation in the rock mass, they are pretensioned by applying the correct torque to the nut holding the support, by V-stringer. This generates compression forces in the roof (Fig. 5). The discussion regarding the application or non-application of pre-tensioning in roof bolting has been ongoing for more than 20 years. The opinions in this respect are strongly divided as regards bolts installed in the roof when there are no cracks. Theoreticians and practitioners alike are more and more often indicating the validity of pre-tensioning in the case of cracked rock masses [8]. Such a situation happens in the case of a roadway support which allows substantial roof deformation before the installation of cable bolts, which is usually performed at a significant distance to the driven excavation. In this case the pre-tensioning of bolts results in the interlocking of rock mass cracks and strata, thus increasing its load capacity. In order to illustrate the point, the results of numerical modelling of the excavation with support reinforced by cable bolts, given the varied values of pre-tensioning, are presented below.

\subsubsection{The principles of numerical model design}

The FEM (Finite Element Method) analysis, utilising the Abaqus calculation system, was conducted on a two-dimensional $55 \times 45 \mathrm{~m}$ model of a rock mass, for a rectangular $2 \times 4 \mathrm{~m}$ roadway. In a homogeneous rock mass model, a $1.5 \mathrm{~m}$ fractured and cracked layer constituted the roof of the excavation. Within this layer, rock mass divisibility was introduced in the form of two sets of discontinuity. The vertical discontinuity distance was $0.2 \mathrm{~m}$, while the horizontal discontinuity distance was $1 \mathrm{~m}$, and created irregular, flat blocks (Fig. 6). The contact between the blocks was described using the classic Coulomb's law with friction coefficient $(\mu)$ equal to 0.6 . A linear elastic physical model of the rock mass was adopted for the calculation. It should be noted that the adopted linear elastic model of the rock mass is greatly simplified in relation to the actual conditions; however, for the objective of calculations, it is sufficient and makes it possible to characterise the phenomena observed in mines in qualitative terms. Displacement and stress boundary conditions were applied in the calculation, i.e. zero displacement of vertical and bottom horizontal edge of the model $\left(\mathrm{u}_{\mathrm{x}}=0\right),\left(\mathrm{u}_{\mathrm{y}}=0\right)$ respectively, normal stress was applied to the top edge with a vertical direction corresponding to the component of the original stress for a depth of $800 \mathrm{~m}$. The support of roadway constituted the primary support reinforced by cable bolts with a length of $5.0 \mathrm{~m}$. The cable bolts are represented in the model by rod elements. The primary, support of roadway is not directly represented in the model. It was assumed that it has a passive impact on the rock mass in the form of pressure on the roadway roof, allowing its significant deformation. Such calculation conditions correspond to the situation in which a zone of fractured, cracked and stratified rock mass is created above the roadway. This is usually observed in real mining conditions above the yieldable support as early as several dozen metres of the face of a driven excavation. Cable bolts were pretensioned some time after installing the support, treated as the basic support of the roadway. In the calculation model, it was assumed that cable bolts are installed in the excavation after reaching $80 \%$ of final convergence which is maintained just in a prop support. Such an approach made it possible to analyse the interaction between cable bolts and the rock mass in the case of pre-tensioning and lack thereof. In the calculations it was assumed that the pretension of bolts $(\mathrm{N})$ was 64 $\mathrm{kN}, 100 \mathrm{kN}$ and $130 \mathrm{kN}$, respectively, which corresponded to the preliminary axial stress on bolts of $203 \mathrm{MPa}, 318 \mathrm{MPa}$ and $414 \mathrm{MPa}$. Assuming the load capacity of cable bolts at 200 $\mathrm{kN}$, which corresponds to normal stresses in the bolt of $636 \mathrm{MPa}$, the pretension was approximately at $32 \%, 50 \%$ and $65 \%$ of the load capacity of cable bolts, respectively. 

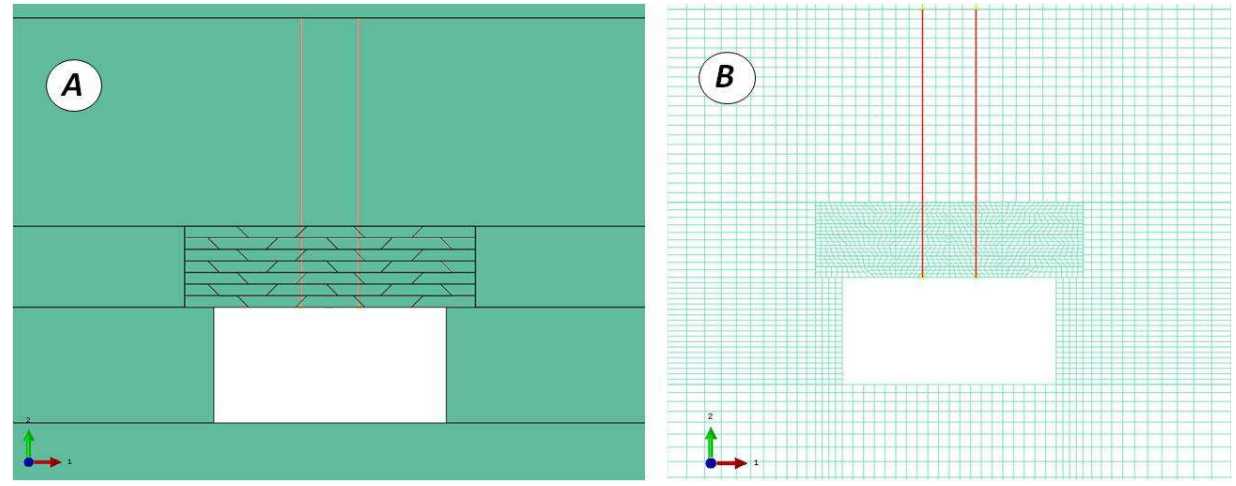

Fig. 6. FEM geometry and mesh of the roadway calculation model.

\subsubsection{The results of numerical calculations}

Delaying the installation of cable bolts until $80 \%$ of final displacement on the outline is reached resulted in the effect of cracked and fractured roadway roof being observed during the installation of the bolts with clear stratification and gaps with a crack with up to $2 \mathrm{~mm}$ (Fig. 7). When cable bolts are not pretensioned, the width of cracks in the roadway roof for its final deformation was nearly $3.9 \mathrm{~mm}$ locally. In this case cable bolts are supporting only the rock mass which has been provisionally slackened by the flexibility of the yielding support. The load on not-pretensioned cable bolts in relation to their load capacity is fairly low. The value of equivalent stress according to the Huber-Mises-Hencky criterion $\left(\sigma_{\mathrm{HMH}}\right)$ amounts to nearly $170 \mathrm{MPa}$, which correspondents to its effort at $25 \%$. If not pretensioned, the bolts work within a small range of their capacity. If the bolts are pretensioned, the rock mass behaves differently. The pre-tensioning of cable bolts in the excavation roof resulted in bracing the blocks of the rock mass into a package of sorts, which is less susceptible to deformation than in the case of no pre-tensioning.

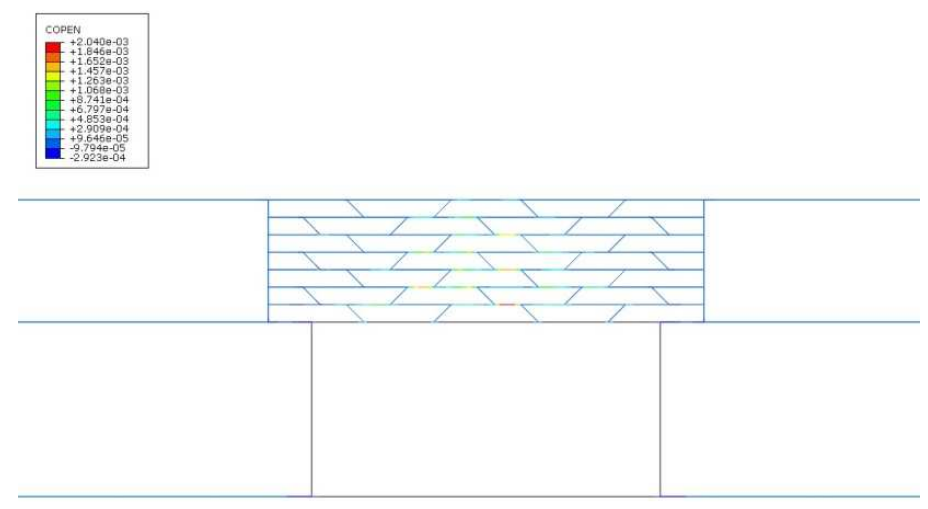

Fig. 7. The crack width (COPEN) map in the context of individual rock mass blocks during the installation of cable bolts.

In the case of pre-tensioning to the maximum level of $130 \mathrm{kN}$, the maximum crack width in the rock mass for the final deformation of roadway outline equals $2.3 \mathrm{~mm}$, and is significantly lower than when no pre-tensioning is applied (Fig. 8). The effort of cable bolts, determined based on equivalent stress $\left(\sigma_{\mathrm{HMH}}\right)$ is, in this case, as much as $481 \mathrm{MPa}$ (Fig. 8), which corresponds to an effort of $75 \%$. 

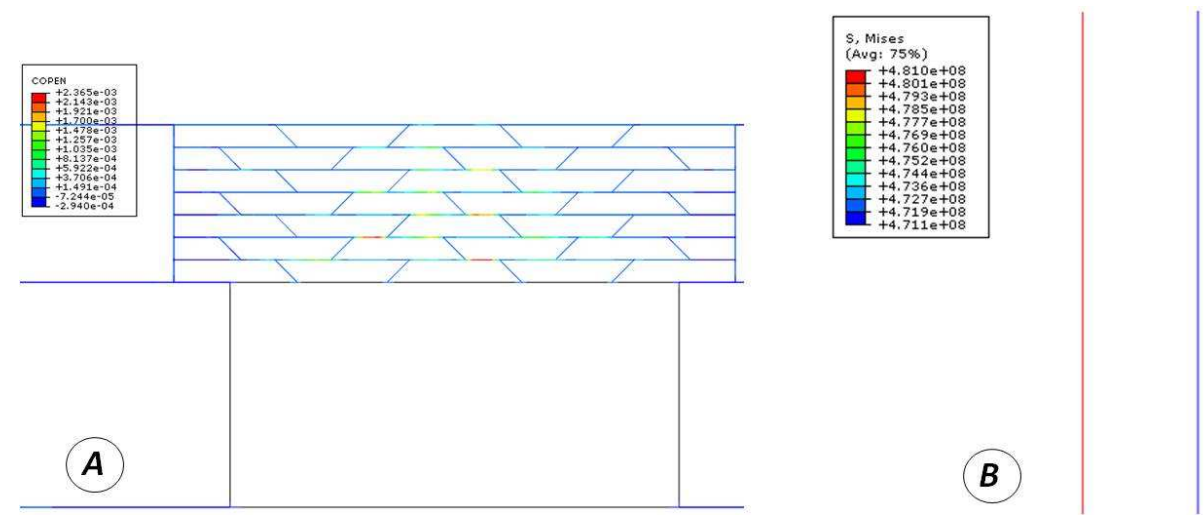

Fig. 8. The crack width (COPEN) map in the context of individual rock mass blocks with pretensioning $(130 \mathrm{kN})$ of cable bolts (A) and HMH equivalent stress in the bolts (B).

As a result of the pre-tensioning of bolts, the cracked rock mass is characterised by greater load capacity than in the case of no pre-tensioning. The greater the tension, the more visible this effect is, and it results in smaller vertical displacements of the excavation roof (Fig.9). Pre-tensioning results in the reduction of cracks and rock mass bracing, therefore increasing its load capacity. A markedly smaller roadway roof displacement is obtained at the cost of greater effort on the part of cable bolts and full utilisation of their load capacity. In summary, pre-tensioning facilitates effective interaction between the cable bolts, cracked rock mass and support.

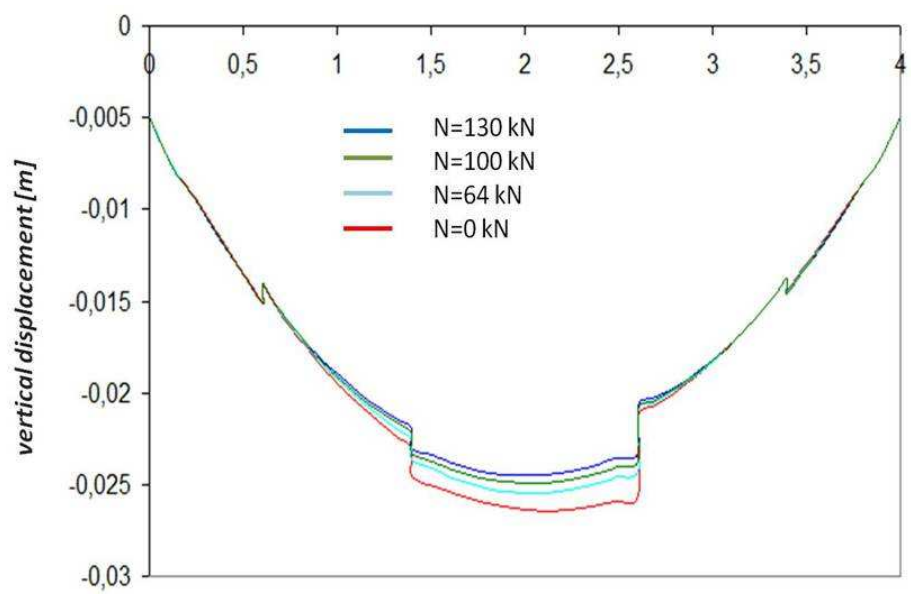

Fig. 9. A chart of final vertical displacements of the roadway roof for various variants of cable bolt pretensioning $(\mathrm{N})$.

\subsection{Pre-tensioning of IR cable bolts in practice}

The observations and measurements of the extent of cracks conducted in excavations secured with a support reinforced with cable bolts do not corroborate the effectiveness of IR bolts in limiting the failure zone in the excavation roof [9]. Under similar geological and mining conditions, one would be hard-pressed to find any differences in the size of these zones in excavations with and without rock bolting using the bolts in question. This poses the question of why this form of rock bolting does not have a significant impact on the condition of the rock mass. This is a relevant question, since increasingly long cable bolts are being used for 
the safe maintenance of the longwall-gateroad junction with disconnected support arches. The effect is further augmented by the increasing depth of mining, the effect of mininginduced changes and the complex tectonics of Polish and Czech deposits. Making cable bolts longer (even to more than $10 \mathrm{~m}$ ) results in a substantial increase in the cost of material and labour connected with the this process. The poor effects of reinforcing the roof rock mass are associated with the intensive convergence of excavations, which results in excessive limitation of their dimensions. The authors propose a thesis that the lack of interaction between IR cable bolts and the rock mass results from the lack of or negligible pre-tensioning and a small number of bolts per square meter of roof excavation. This, in turn, results from the design of the threaded bolt joint. Tests carried out in OKD 2 on IR-6 bolts prove the above. Taking into account the parameters of the IR- 6 bolt head, we obtain a ratio of torque to tension of approximately 9.8. This means that a torque of $400 \mathrm{Nm}$ on the nut of the bolt results in a pretension in the bolt strand of $40.82 \mathrm{kN}$ only. At this point, it is worth highlighting that reaching this value of torque is impossible when using standard bolting rigs in Polish hard coal mines. In real conditions, it is required to use a wrench with an elongated arm and apply manual effort. Tests regarding the installations of IR- 6 bolts, equipped with Glötzl KN 500 A50 dynamometer, were performed in OKD 2 and supervised by Ing. Pavel Dvořák. Of course, the objective of these tests was to determine not only the actual values of pretension in mining pit conditions, but also the course of changes in bolt load over the long time of excavation maintenance. In total, 6 test bolts with dynamometer were installed. The manner of their installation was always the same. The bolts were installed on 3 cartridges of Lokset resin using STB 1700/1500 2S devices, followed by mechanical and then manual tightening of the bolt nut to $400 \mathrm{Nm}$. The values indicated by the dynamometer immediately after applying this torque reached the level from 10 to $45 \mathrm{kN}$. As can be seen, the values obtained differ significantly from the theoretical value. The main reasons for this are probably the limitation of tension resulting from friction between the individual components - nuts and washers - and impurities in the bolt head thread. Whatever the cause, it should be noted that the IR bolts, commonly used in the Polish and Czech mining industry, make it impossible to reach a relevant level of pre-tensioning. As a result, the interaction between the bolts and the rock mass is significantly restricted, and their impact on the development of the failure zone in the roof is rather insignificant.

\section{A proposed change to the system of reinforcing the support with cable bolts}

The growing problems with maintaining the stability of excavations are caused by the increasingly difficult geological and mining conditions, and make it necessary to adopt a brand-new approach to the technique of reinforcing the support with roof bolting. We need cable bolt solutions whose active impact on the rock mass will result in increasing its load capacity. The utilisation of cable bolt only to "suspend" the elements of the support is an archaic solution which is poor in engineering terms, whose application can be justified only in very favourable rock mass conditions. According to the authors, for the Polish mining industry, it would suffice to adapt the solutions proven in many other countries, where roof boltings play a much greater role. The proposal described below is based on two bolting systems, Titan Bolt (by DSI) and Sumo Bolt (by Jennmar), which are very similar in terms of design. The presented solutions are among the systems characterised by the highest load capacity in the coal mining industry. The strands are composed of twisted wires with evenly spaced bulbs. In the middle of the strand, there is a steel tube which is used to pump the binder (mineral or resin). The bolt joint is a typical barrel and wedge system. The method of reinforcement bolting in excavations secured with a support proposed by the authors is described in detail below. First, in an excavation secured with steel arch yielding support, a 
hole with an appropriate length and diameter is bored several dozen metres from its face (Fig.10). At that point, the flexibility of the arch support and impact of the rock mass cause the roof surrounding the excavation is already cracked. The Titan or Sumo bolts are installed within the hole on two resin cartridges, with the barrel and wedge installed in place and pretensioning being applied using a hydraulic cable tensioner. Applying the pretension (usually 200 to $300 \mathrm{kN}$ ) directly to the roof results in the closure of some cracks and compression of rock strata in the immediate roof [10].
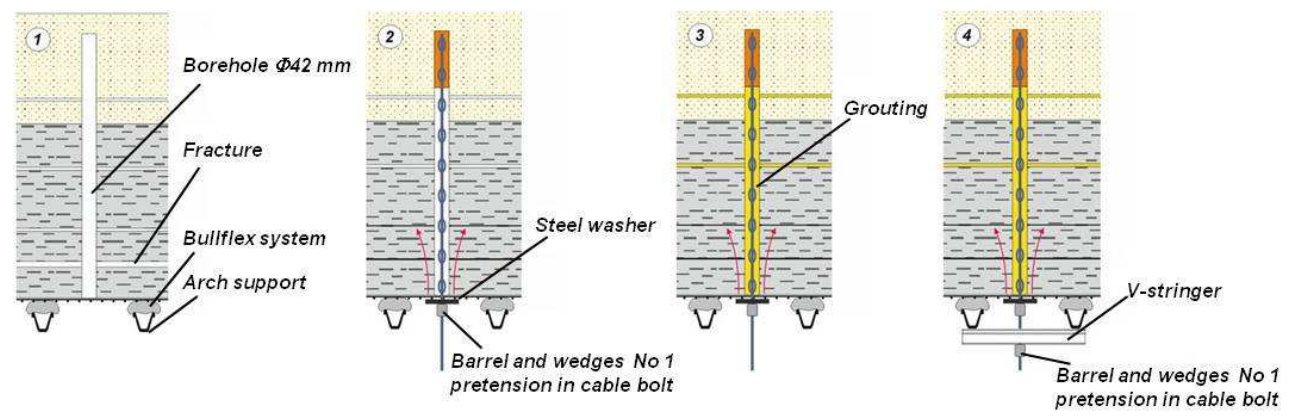

Fig. 10. Cable bolt installation.

A bolt constructed in this manner interacts with the rock mass from the very beginning, limiting the rate of cracking. The second stage usually takes place immediately after the first stage or after a slight delay. In this stage, mineral binder or liquid two-component synthetic resin are fed under pressure (Fig. 10). That way, an adhesive connection between the rock mass and the bolt, along its entire length, is obtained with cracks (not closed in stage 1) being filled and rocks becoming bonded. The last stage is the suspension of support arches on the protruding end of the bolt to facilitate the remove of several sidewall arches at the intersection with the wall. A steel $\mathrm{V}$ binding joist is built over the two adjacent arches and fixed with another barrel and wedge (Fig. 10).

\section{Summary}

The analyses and calculations presented in this article aimed at indicating the imperfections of the solutions used in Poland and the Czech Republic for reinforcing the yielding support with cable bolts. The impossibility of pre-tensioning and binding IR bolts along a short section results in their interaction with the rock mass being substantially limited. The increasing depth of mining (exceeding $1000 \mathrm{~m}$ ) and complicated geological and mining conditions force mines to search for more effective ways of reinforcing excavation supports. The bolting techniques presented in Chapter 3 make it possible to eliminate the previous errors. According to the authors, they will result in a marked improvement of the stability of the support and roof of excavations. The method also facilitates disconnecting the sidewall arch at the longwall-gateroad junction without application of additional props.

Article prepared as part of statutory work No. 11.11.100.005

\section{References}

1. A. Wardas, R. Bobek, T. Śledź, J. Twardokęs, A. Ratajczak, P. Głuch, Ground control for ensuring the stabilisation of roadways located at considerable depths in the conditions of natural and mining risks, Zeszyty Naukowe Instytutu Gospodarki Surowcami Mineralnymi i Energią Polskiej Akademii Nauk 94, 53-66 (2016) (in Polish) 
2. P. K. Kaiser, C. Ming, Principle of rockbolting design, Journal of Rock Mechanics and Geotechnical Engineering 4, 215-227 (2012)

3. K. Skrzypkowski, E3S Web Conf. 29, 00004 (2018) doi: 10.1051/e3sconf/20182900004

4. Z. Rak, J. Stasica, Z. Rawicki, Selected problems in using roof bolting for the reinforcement of chock support in preparatory excavations, Bezpieczeństwo Pracy i Ochrona Środowiska w Górnictwie 2, 3-13 (2016) (in Polish)

5. P. Małkowski, Z. Rak, J. Stasica, Elements of constructing mechanical lining in the light of previous experience, Prace Naukowe GIG, Problemy Współczesnego Górnictwa 1/1, 316-326 (2011) (in Polish)

6. P. Małkowski, Z. Rak, Influence of mechanical lining on the state of stress around a gate drifted in weak carboniferous rocks, Prace Naukowe GIG, Problemy Współczesnego Górnictwa 1/1, 251-262 (2011) (in Polish)

7. M. Rotkegel, S. Stałęga, W. Węzik, W. Schopp, Improving the work conditions of support through the application of mechanical lining, Prace Naukowe GIG, seria Konferencje - Systemy obudowy wyrobisk korytarzowych dla zapewnienia stateczności i poprawy bezpieczeństwa pracy, Katowice, 151-158 (2007) (in Polish)

8. M. Cała, J. Flisiak, A. Tajduś, Interaction between rock bolts and complex geology rock mass, Biblioteka Szkoły Eksploatacji Podziemnej, Wydawnictwo Instytutu Gospodarki Surowcami Mineralnymi PAN, (2001) (in Polish)

9. W. Korzeniowski, Ł. Herezy, K. Krauze, Z. Rak, K. Skrzypkowski, Rock mass monitoring based on the analysis of the work of the powered roof support, Wydawnictwa AGH, (2013) (in Polish)

10. J. Stankus, X. Li, D. Giza, M. Rutyna, Rock wall bolting and grouting: the application of SUMO bolts in Western U.S. Longwall Recovery, Materiały konferencyjne: XXI Międzynarodowa Konferencja Naukowo-Techniczna z cyklu górnicze zagrożenia naturalne 2014, Zagrożenia naturalne a bezpieczne i efektywne Kopalnie, 35-37 (2014) 